\title{
Children as Co-ethnographers of their Plurilingual Literacy Practices: An Exploratory Case Study
}

\author{
GAIL PRASAD \\ Ontario Institute of Studies in Education
}

\begin{abstract}
Interdisciplinary childhood researchers have begun to advocate a shift from conducting research about children to engaging children themselves in the research process. In this article, I reflect on issues and insights that arose while working with grade 5 students as ethnographers of their own language and literacies practices over the course of a sixmonth transformative multiliteracies classroom intervention in a French school in Toronto, Ontario, Canada. I describe this initial exploratory case study as a way of provoking discussion on ways we may re-envision plurilingual multiliteracies research with children as co-researchers.
\end{abstract}

\section{Introduction}

"There are stories inside everyone."

--student, age 10

Over the past decade, the concept of plurilingualism has developed to describe the inter-related repertoire of linguistic skills and practices that individuals draw on for different purposes in a variety of contexts (Dagenais \& Moore, 2008; Garcia, Bartlett \& Kleifgen, 2007; Moore, 2006; Zarate, Lévy \& Kramsch, 2008). Although an increasing number of students speak different languages at home, in their communities and at school, students' plurilingual repertoires have not traditionally been affirmed in the classroom (Castoletti \& Moore, 2009; Cummins, 2001; Garcia, Skutnabb-Kangas, \& Torres-Guzmán, 2006; Wong-Fillimore, 2005). The consequence of ignoring the resources that culturally and linguistically diverse (CLD) students bring to their learning is that schools more often produce monolingual graduates rather than plurilingual citizens (Coste \& Simon, 2009; Cummins, 2009, in press; Jedwab, 2004; Wong-Fillimore, 2000). Extant research concerning linguistic diversity in Canadian schools has traditionally been conducted by adult researchers investigating adult perspectives on children's language learning such as teachers' and administrators' views of and practices with CLD students, and parents' motivations for their children (e.g. Corsaro 1981, Dagenais \& Berron, 2001; Knupfer, 1996; Peterson \& Heywood, 2007). Interdisciplinary childhood studies researchers, however, have recently begun to advocate a shift from conducting research about children to engaging in research with children as co-researchers and informants (Albanese, 2009; Belanger \& Connelly, 2007; Bucknall, 2012; Christensen \& James, 2008; Freeman \& Mathison, 2009, Prout, 2005).

What might we gain by collaborating with CLD children as co-researchers to learn how they view their plurilingualism and their plurilingual multi-literacies? A 
number of questions arise when we consider engaging in research with children as coethnographers of their own language and literacy practices. In general, what are the possibilities for and limits of researching with children about their own literacy practices rather than researching about children's literacy practices from adult perspectives? How might our research practices need to be re-visioned to build on CLD children's competencies? How might we disseminate research with CLD co-researchers in ways that are reflective of and responsive to their literacy practices and their perspectives? What should be the criteria for evaluating such collaborative research? In this article, I reflect on early insights and issues that arose through an exploratory transformative multiliteracies case study that I conducted from January to June 2012 with a class of grade 5 students about their experiences and practices as plurilinguals. This case study is part of a larger doctoral inquiry with students from English and French schools across the Greater Toronto Area. I begin herein by sketching the backdrop for the case study, reported in this article, in the context of the overall multiple case study. Then, I briefly highlight the theoretical and methodological underpinnings, along with the research questions that guide this inquiry. Next, I outline the research design with particular attention to the creative visual and multimodal methods used to engage children throughout the inquiry process. To illustrate these methods in practice, I provide examples of data generated with children during the initial case study in a private French International school in Toronto. The remainder of the article is then devoted to a discussion of preliminary findings from the transformative multiliteracies intervention in this first school case as a way to provoke further reflection regarding the engagement of children in plurilingual multiliteracies research.

\section{Study Background}

In the 2006 Census, Ontarians reported more than 200 languages as "mother tongue"; Ontario continued to be the province of choice for more than half of the 1.1 million newcomers who arrived in Canada during the 2001-2006 period. Accordingly, a growing proportion of students across Ontario speak a language other than English or French at home, at school and in their communities; cultural and linguistic diversity characterize English and French schools, particularly in urban centres. At the same time, Ontario's three main public schooling models each have distinct linguistic mandates: mainstream English schools use English as the language of instruction for both anglophone and English-language learners; French-immersion schools aim to support students' French-as-a-second language development by using French as the language of instruction across the curriculum; and, French-language schools provide education in French (as a first language) to francophone minority students. Research over the last decade has highlighted the increasing need to support CLD students within each specific school model: mainstream English schools (Cummins, 2001; Goldstein, 2003; Heydon \& Iannacci, 2008; Smythe \& Toohey, 2009); French-immersion schools (Dagenais \& Berron, 2001; Dagenais \& Moore, 2004, 2008; Swain \& Lapkin, 2005; Taylor, 2009); and French-language minority schools (Prasad, 2012; Farmer \& Labrie, 2008; GérinLajoie, 2003, 2006, 2008; Masny, 2009). Although researchers have examined perspectives and practices within specific school models, there is a gap in Canadian scholarship comparing CLD children's language learning across English, French and 
French-immersion schools within a province or territory. This gap is significant within the Canadian context where education mandates and policy fall under provincial jurisdiction and as such can vary province by province.

The case study reported here is part of a broader inquiry that engages students from four different English and French schools across Toronto as co-researchers of their plurilingual practices and experiences through the classroom-based implementation of 'transformative multiliteracies pedagogy' (Cummins, 2009). This comparative study of CLD students' plurilingual experiences across Toronto's schools is particularly timely, given the Ontario government's 2009 release of Ontario's Equity and Inclusive Education Strategy (OEIES). The OEIES applies across the three aforementioned public school models and this policy statement subscribes to an understanding of students' diversity as a resource for learning, highlighting the need for educators to adopt pedagogical practices that affirm the plurality of their students' identities (Ontario Ministry of Education, 2009).

This article reports on the first exploratory case study conducted in a private French international school in Toronto. This private French international school was selected as the first case because it provided an opportunity to pilot research activities with student bilingually in French and English in a context that explicitly promotes plurilingualism in alignment with the Common European Framework of Reference on Languages (CEFR). (Council of Europe, 2001). Recent research on plurilingualism has found that the global network of French international schools uniquely supports students' plurilingual and plurilicultural awareness and development as they provide a unique meeting place for CLD students. (Ceginskas, 2010; Coste \& Simon, 2009). Ceginskas (2010), in particular, has highlighted that international schools,

[S]erve as meeting points for different backgrounds and simultaneously provide evidence that various combinations of linguistic, cultural and ethnic background exist. This is a positive feedback for multilingual individuals outside of their home environment [...] [T] he greater awareness of linguistic and cultural diversity as offered by international schools provides the possibility of reconfiguration and opens up boundaries to enable moving from the periphery to inclusion. (p. 9-10)

In addition, the site of the French international school allowed me to pilot my research tools and to wrestle with epistemological and methodological issues in a school guided by the CEFR, while at the same time, working with a population who to some degree by virtue of living in Toronto were acquainted with the Canadian context. While the data collection for this multiple case study was in progress (2011-2013), the Ontario Ministry of Education was also working toward the adoption of the CEFR as a resource for FSL instruction.

\section{Theoretical Lenses}

Inspired by Lahire's notion of the 'Plural Actor' (2011) and growing studies on plurilingualism in schools (Coste, 2005; Dagenais \& Moore, 2008; Garcia, Barlett, \& Kleifgen, 2007; Gérin-Lajoie, 2008; Moore, 2006; Zarate, Lévy, \& Kramsch, 2008), this 
research examines students' representations of their plural identities through the practice of "Transformative Multiliteracies Pedagogy" (TMP) (Cummins, 2009). Lahire (2011) theorizes that over the course of their lives, individuals develop as "plural actors" rather than singular beings:

We live experiences that are varied, different and sometimes contradictory. A plural actor is thus the product of an - often precocious experience of socialization in the course of their trajectory, or simultaneously in the course of the same period of time in a number of social worlds and occupying different social positions. We can therefore propose the hypothesis of the embodiment by each actor of a multiplicity of schemes of actions [...] and habits [...] organized around so many repertoires and the pertinent social contexts that they learn to distinguish and often to name - via the ensemble of their previous socialization experiences. (p. 31-32)

Lahire argues that as social scientists, we must consider the ways in which a plurality of worlds and experiences are integrated into the fabric of each person's being and that in order to understand the individual, we must observe their actions in a variety of settings. Lahire's theorizaton of the individual as a plural actor provides a particularly helpful framework to analyze children's pluricultural and plurilingual identities because it invites an examination and accounting of the diverse practices and experiences that contribute to students' plural identities including their home cultural and linguistic practices, their community linguistic landscape, as well as their classroom and school experiences.

Coste and Simon (2009) have extended Lahire's notion of the plural actor to assert the role of schools in helping students to be(come) "plurilingual social actors." They argue that although plurilingualism is increasingly the norm,

[I]ndividual plurilingualism is unfortunately not in itself a guarantee of acceptance and tolerance of the diversity of others, and this may well be a result of building our identity on just one identifying language [at school]. What is needed then, in educational terms, is development of plurilingual and plurilicultural competence in order to foster a relaxed and welcoming relationship with language diversity and encourage open-ended cultural affiliation. (p. 174175)

For this study, the principal unit of analysis is the individual child as a plurilingual social actor in the context of his or her family, school and broader community. Although the French concept of plurilinguisme is often translated in English scholarship as multilingualism, the terms multilingualism and plurilingualism have in their original uses different foci: whereas multilingualism has traditionally referred to the study of the societal contact of languages, plurilingualism has developed as the study of individual's repertoires and agency in more than one language (Moore \& Gajo, 2009). In addition, the traditional view of multilingual speakers is historically rooted in a 
monolingual assumption that such speakers would develop separate mastery of multiple languages with the ultimate goal of becoming an 'idealized native speaker' in each language. By contrast, more recent sociolinguistic studies have focused on two critical inter-related aspects of plurilingualism:

(1) the bi/plurilingual person uses two or more languages - separately or together for different purposes, in different domains of life, with different people; and (2) the view that, because of the needs and uses of several languages in everyday life are usually very different, plurilingual speakers are rarely equally or entirely fluent in their languages." (Moore \& Gajo, 2009, p.141)

The view that plurilingual speakers possess uneven competence across many languages fosters a focus on the linkages across languages rather than a focus on languages as separate/isolated components within children's linguistic repertoires. (Coste, 2001). This holistic view of plurilingual speakers' competencies is foundational for supporting CLD learners in schools because it views such learners from an asset-oriented perspective in terms of the plurality of the skills and competence that they possess rather than in terms of the school language which they are perceived to lack.

This additive orientation language learning is central to Cummins' (2009) Transformative Multiliteracies Pedagogy (TMP). TMP is based upon the multiliteracies framework proposed by the New London Group (1996) that conceptualizes literacy as encompassing not only the cognitive skills associated with reading and writing, but also the social practices associated with language. The New London Group originally articulated four dimensions involved in a pedagogy of multiliteracies: situated practice, overt instruction, critical framing and transformed practice. Cummins (2009) integrates these dimensions with particular focus on transformative practice to support the literacies development and practice of CLD learners. Transformative Multiliteracies Pedagogies (TMP) is built on the following five principles:

1. TMP constructs an image of the student as intelligent, imaginative, and linguistically talented; individual differences in these traits do not diminish the potential of each student to shine in specific ways.

2. TMP acknowledges and builds on the cultural and linguistic capital (prior knowledge) of students and communities.

3. TMP aims explicitly to promote cognitive engagement and identity investment on the part of students.

4. TMP enables students to construct knowledge, create literature and art, and act on social realities through dialogue and critical inquiry.

5. TMP employs a variety of technological tools to support students' construction of knowledge, literature, and art and their presentation of this intellectual work to multiple audiences through the creation of identity texts. (Cummins, 2009, p. 50-51) 
Cummins' (2001) notion of 'identity texts' was originally conceptualized from a pedagogical standpoint as a way to engage CLD students in building and sharing their literacy expertise. This present inquiry reflects on how "identity texts" can further function as powerful research representations. Pahl and Roswell (2007) have similarly made a case for examining children's multimodal literacy productions - texts as artifacts into which multiple or layered identities are sedimented. The present inquiry similarly endeavours to engage students as co-researchers in the collaborative production of individual and collective "identity texts" and to reflect on the process of their creation in order to access children's views of their plurilingualism and plurilingual literacy practices.

\section{Reconceptualizing Data Collection as Data Generation: Co-constructing Knowledge with Children using Creative Multimedia.}

I employ the creation of "identity texts" with teachers and sudents as a research methodology in which the product and process offer interwoven representations of children's plurilingualism and plurilingual literacy practices. In this way, the traditional data collection process becomes one of data generation with children as co-researchers. The difference between collecting data from children and generating data with children is more than semantic; this distinction necessitates a paradigm shift that regards the research process as iterative, in which engagement in the creative process of data generation builds knowledge and understanding that in turn deepens students' creative processes, reflection and engagement in the inquiry.

Accordingly, I purposefully prioritize the arts throughout the research design as a strategy to engage children actively in the data generation process. Creative arts-informed techniques have been used in research specifically to enable CLD children to express their perspectives without being limited to using language of instruction and so scaffolding their co-creation of knowledge (Auger, 2010; Butler-Kisber, 2010; Freeman \& Mathison, 2009; Molinié, 2009). Gauntlett and Horlzwarth (2006) describe creative visual methods in particular as offering,

an enabling methodology - it assumes that people have something interesting to communicate and that they can do so creatively[...] by inviting participants to create things as part of the research process, it's a different way into a research question[...] and engages the brain in a different way. (p. 84)

Arts-based pedagogies allow children to represent their thinking visually through a variety of media in which they feel comfortable and fluent (Castellotti \& Moore, 2009). As such, they support the current shift in childhood studies described above, from conducting research about children to collaborating in research with children. Researchers have begun to advocate the adoption of visual (Freeman \& Mathison, 2009; Molinié, 2009; Thomson, 2008) and participatory methods (Albanese, 2009; Bucknall, 2012; Christensen \& James, 2008; Freeman \& Mathison, 2009) that support children in the process of articulating their views, and adults in understanding them. Indeed, a growing body of research with children as subjects, agents and/or researchers highlights how arts-informed research tools such as drawing and photography more effectively 
engage children in research than traditional qualitative data collection tools like interviews (Cappello, 2005; Freeman \& Mathison, 2009; Kendrick \& Jones, 2004; Kendrick \& Mckay, 2008; Thomson, 2008). The inclusion of creative visual methods in the present inquiry was not simply a methodological choice motivated by a desire to facilitate children's collaboration as co-researchers, but rather more deeply rooted in the epistemological understanding of children as legitimate 'knowers' of their own language and literacies practices with insider perspectives that can best be voiced and interpreted by children themselves.

\section{Research Questions}

The research study is guided by three main questions: How do culturally and linguistically diverse (CLD) students conceptualize their pluri-literate identities in Ontario's English, French-immersion and French-language schools? Second, how do prevailing language policies influence how CLD students' develop literacy expertise at school in English, French-immersion and French-language classrooms; and to what extent does the classroom enactment of such policies impede and/or enable CLD learners to fashion pluri-literate identities? Third, how can (Cummins, 2009) support CLD students' plurilingual literacy expertise development and engage them in be(com)ing coresearchers of their language and literacy practices? Just as Dagenais and Jacquet (2008) have advocated for integrating scholarship in both English and French, the comparative design of this study further investigates what can be learned, gained and shared about 'Tansformative Multiliteracies Pedagogy' and students' plurilingualism by comparing practices across English and French contexts.

\section{Research Design: Methods \& Methodology}

This comparative inquiry consists of four case studies in English and French schools in Toronto: one mainstream class in an English public school; one public French immersion school; one public French-language minority school; and one private French International school. Whereas the first three schools all fall under the jurisdiction of provincial education and federal language policies, the fourth school operates according to the mandate of the French Ministry of Education and is guided by language policies and programs developed by the Council of Europe such as the Common European Framework of Reference for languages (CEFR) (Council of Europe, 2001). As described earlier, the French international school in Toronto that is the focus of the present article, was selected as the initial case because it provided an opportunity to pilot research activities with students bilingually in French and English in a context that explicitly promotes plurilingualism in alignment with the CEFR (Council of Europe, 2001). Data collection in the three public schools will be completed by the end of 2013. I first describe the study methodology and data generation activities across all four sites, and then focus on insights from the activities in the French international school.

The first phase of the research involves analysis of official language and education policies concerning each school context. In Canada, language policies and official bilingualism are mandated federally while education falls under provincial jurisdiction. A number of studies have examined how such a division has resulted in unequal access of CLD immigrant and indigenous children to language resources in 
education (Mady, 2006, 2007; Majhanovich, 2010; Prasad, 2012; Ricento \& Cervatiuc, 2010; Taylor, 2009). Policy analysis, teacher interview and classroom observation provide complementary data to understand how teachers enact language and education policies in their respective classrooms. In this regard, I focused not on the broad macro policies on official bilingualism set forth by the Canadian government, or by the Ontario provincial government, but rather on how these macro-level policies are instantiated in the micro-policies and practices of classroom teachers and school administrators. As Ramanathan and Morgan (2007) have argued, practitioners such as teachers can play a critical role resisting, subverting and challenging official macro-language planning and policy hierarchy. I approach the local classroom as a site in which official government policies and strategies are, in the words of Ramanathan and Morgan (2007) "directly experienced and sometimes resisted. And it is from these direct experiences and conflicts that relevant and creative innovations around policy arise" (p. 449). This initial case study thus considers how the classroom teachers and school administrators' policies and practices facilitated and challenged students' plurilingual practices within school space.

Within the overall comparative inquiry, the second phase of each school case study involves a collaborative implementation of Transformative Multiliteracies Pedagogy with at least one class of junior level (grade 4-6) students in each school setting. The junior level was selected because all students in Ontario begin instruction in their second official language by grade 4 and as such, all students in all school cases are engaged in some capacity in the process of second language learning. In the initial case of the private French International school, students receive instruction in both English and French from Kindergarten. Figure 1 outlines the design for each school case study. Although the focus is on giving voice to students' perspectives and representations of plurilingualism, parents, teachers and administrators are also invited to participate in interviews at the culmination of each case study.

Each multiliteracies classroom intervention was designed to take place over approximately 10 weeks, as agreed to by the participating classroom teacher, school administrator and school board. The intervention involves students in a number of individual and group activities that generate a range of representational artifacts. The motivation to engage students in a variety tasks is to enable them to become coethnographers of their own language and literacy practices: the 'mosaic' of the representational artifacts they generate throughout the inquiry enable them to make visible complex, insider perspectives on how children themselves understand their plurilingual lives and literacies (Clark, 2004). In practice, the length of each classroom intervention varied from one class to another depending on how students and teachers decided to take up each of the activities. 


\section{School Research Design}

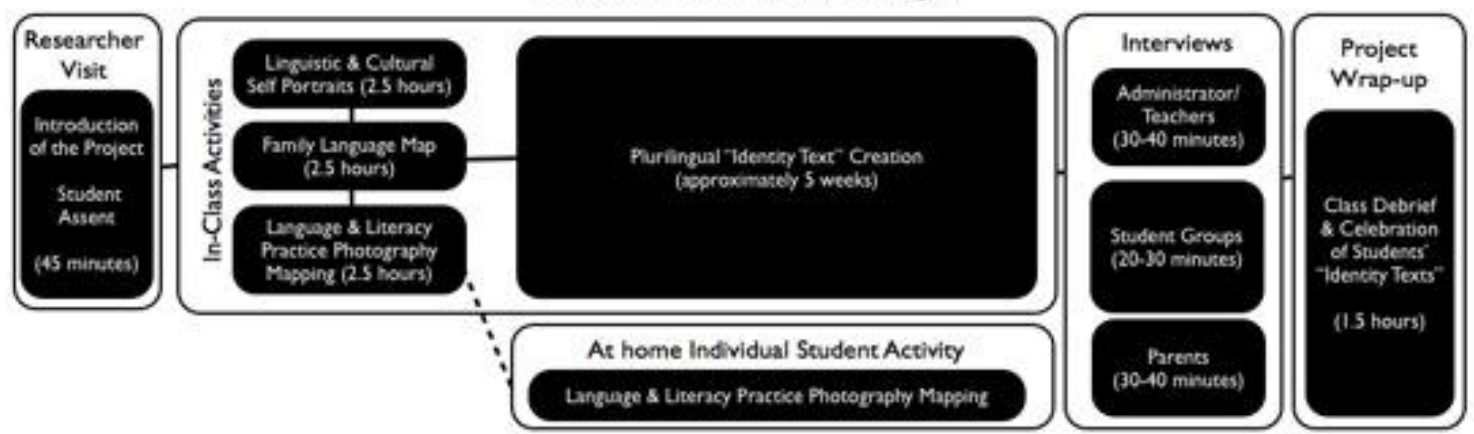

Figure 1: Transformative plurilingual multiliteracies case study design

\section{Linguistic Portraits and Family Language Maps}

In keeping with the arts-informed methodologies described above, at the outset of the study I invited children to introduce themselves to me by creating linguistic and cultural self-portraits that reflect the linguistic and cultural resources they bring to their classrooms. I developed the linguistic self-portrait conceptual tool for children based on Busch's (Busch, Jardine \& Tjoutuku, 2006; Busch 2010) models working with teachers. Krumm (2008) and Martin (2012) provide additional examples of language portraits with children. In my adaptation of this activity, students begin by creating a paper collage as a background for their self-portraits. Students first associate a colour with each language or culture they consider to be a part of their lives. Then, they tear pieces of coloured paper to represent proportionally their relationship to each language or culture; that is, a student may use more of one colour to illustrate that he feels a stronger attachment to the corresponding language, or a student may use less of a colour to demonstrate her limited use of that language in her daily life. After completing their paper collage background, students cut out a black and white outline of their body generated in Photoshop from a digital photograph to map on their bodies the different languages and cultures that play a role in their life. Students make choices regarding the colours they use to represent each language, as well as where they place each language or culture on their 'body'. This creative process enables students to engage in a reflective process about their languages and cultures in their lives and to use colour and embodied metaphors to describe their feelings, use and relationship with each language and culture. 


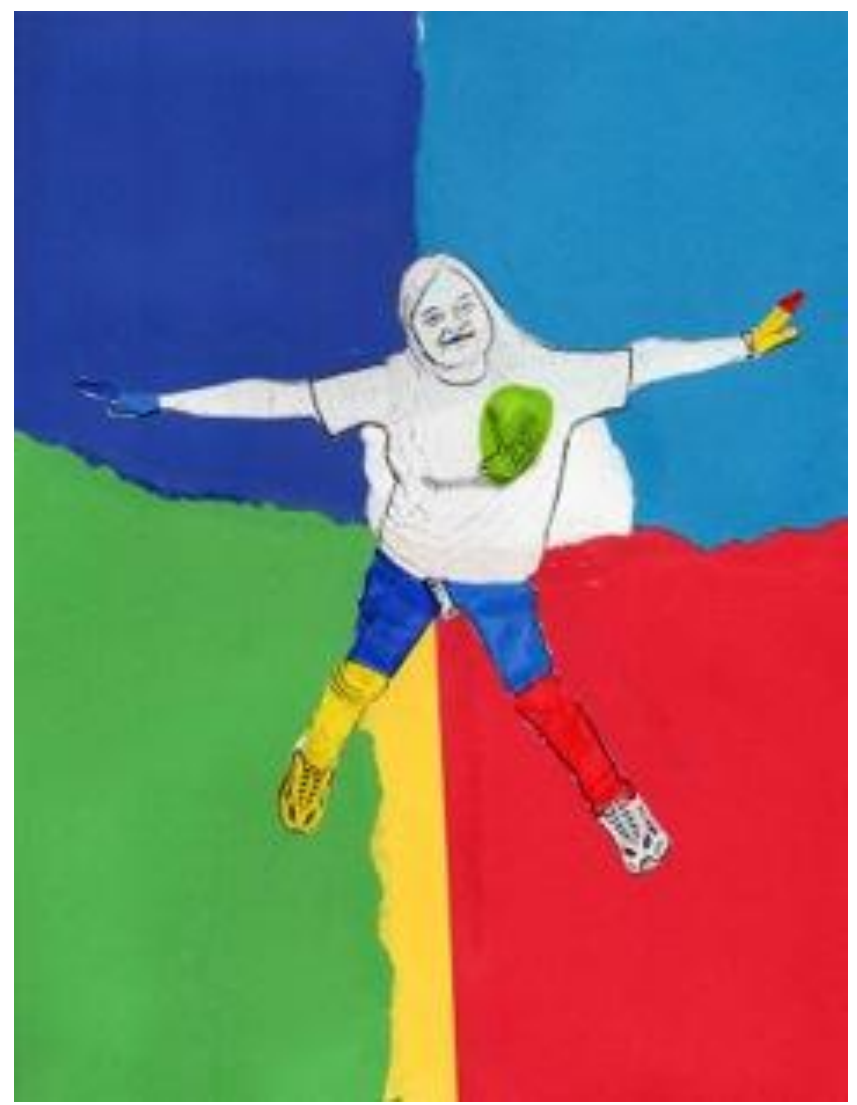

Figure 2: Language portrait, CM1 student

Figure 2 provides an example of Yasmine's ${ }^{\mathrm{i}}$ portrait, a student at the French International school since petite section.. Her mother is Iranian and speaks Farsi as a first language; her father is French Canadian from Quebec. Yasmine has attended the French international school from kindergarten when her family moved to Toronto from Quebec. The principal language of communication at home is French. On her portrait, Yasmine used blue to represent French. Although she distinguishes between French from France (dark blue) and French from Quebec (light blue), the background of her portrait is mostly blue because she uses French most of the time. The next two languages that she includes are English (red) and Farsi (green). Yasmine learned English with babysitters as a preschooler and then at school, and with some of her friends. She uses Farsi with her grandparents on her mother's side and to some extent with her mom and younger sister. Yasmine also represents her growing knowledge and interest in Spanish because her family frequently travels to Barcelona and her mother speaks Spanish as a result of living and working there for a period of time. Yasmine will be taking Spanish as her "third" required language at school in grade 6. Finally, Yasmine included a small part of her background in white to represent a memorable trip to Switzerland where she was exposed to the use of German and French.

In terms of mapping her languages on her body, Yasmine puts her languages mainly on her legs and feet as she believes that her ability to speak different languages allows her to travel and move in different places more easily because she can 
communicate with other people in those places. In addition, she puts French, English and Spanish on her hands because she interacts with those languages. On her mouth, Yasmine colours French, English, Farsi and Spanish as she sees herself as a speaker of all four languages. Finally, Yasmine reserves her heart for her cultural identification as Iranian; she explains, "most of my family is from Iran". Students' language portraits make visible their thoughts, feelings and attachments to different languages and colours and then provide scaffolding for detailed narrating of their linguistic and cultural autobiographies (Farmer, 2012; Prasad, accepted).

Children's voices and perspectives are clearly essential in the interpretation of their portraits because they are responsible for and understand the personal choices they have made in their self-representations. Their creation of the self-portrait allows them not only to represent their cultural and linguistic identities, but also to take on identities of competence (Manyak, 2004) as creative, linguistically talented plurilinguals who can speak with authority about their experience. 'Language biography' is one of the three central elements of the European language portfolio used by many members of the European Union. Within the initial case study reported on herein, the process of creating a visual 'language biography' before sharing a narrative account of their language learning and practices allowed students to make sense of their thoughts, memories and ideas by manipulating concrete materials (paper, glue, scissors and markers). Busch (2010) explains that,

Processes that influence language use tend to operate unconsciously and cannot easily be verbalized. The switch in mode of representation from word [spoken or written] to image [visual] helps to deconstruct internalized categories, to reflect upon embodied practices and to generate narratives that are less bound to genre expectations. While the logic of the word is characterized by a time-bound linear sequence, visual representation is characterized by space and simultaneity and requires attention to the ways in which the various components of the picture relate to each other. (p. 286)

Students use their visual cultural and language portraits to construct their own language biography narrative. The creative visual artifact provides cues to facilitate their narrative telling and stimulates questions from other students and the researcher that might not have surfaced without the visual aid.

After creating their self-portraits, students then create family language maps inspired by the work of Dagenais and Berron (2001), as well as Smythe and Toohey (2009). In this activity, students create a family language map to illustrate patterns of language use among their family members at home. Students' language portraits and family language maps are the starting point for student interviews and class discussion about linguistic and cultural diversity. These creative visual activities enable children to take on roles not only as artists, but also as knowledgeable co-researchers. In the process of articulating their choices about the colours of languages and cultures, their proportions and placement on their bodies for their self-portraits, as well as their symbolic representation on their family maps, these visual aids provide access to emic views of children's plurilingualism and literacy practices. The classroom teachers in the French 
international School further used these arts-informed activities to scaffold students' writing in a reflective journal response, and video recorded oral presentations about their portraits. (See Figure 3: "Moi, je suis plurilingue!" movie screenshot) In this way, the non-verbal, creative expression and experimentation provided students with reflective personal space to rehearse their thinking prior to producing a more formal written and oral text for the class.

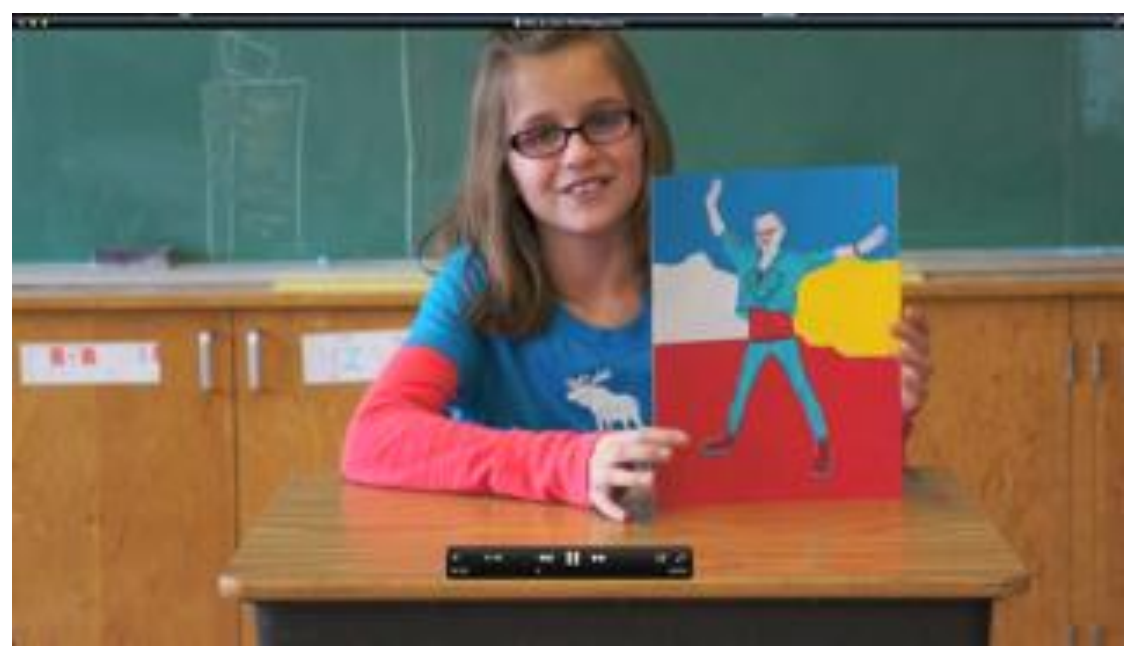

Figure 3: "Moi, je suis plurilingue!" movie screenshot

\section{Linguistic Landscape Mapping at School and at Home}

After students completed their self-portraits and family language maps, they used digital cameras to map the linguistic landscapes of their school and home. Following recent studies including Dagenais, Moore, Sabatier, Lamarre and Armand (2009) and Smythe and Toohey (2009), students first worked in groups to document through photography their reading and writing in any language or mode at school. As coresearchers, student then analyzed photos by categorizing them according to studentgenerated themes. In this way, students are engaged in the analysis of the visual data generated in their photography, as well as in the documentation of literacy practices and linguistic diversity at school. Upon completing this group photography exercise at school, individual students borrowed digital cameras to photograph their reading and writing in any language and any mode in their home life environments. In the context of an interview with the researcher, students were invited to group their photos into selfgenerated categories. This contributed to the joint analysis of students' home literacy practices. Finally, students compared photographs taken at school and photographs taken at home to reflect on similarities and differences between school literacy practices and home literacy practices. It was critical for students to have hard copies of photos to sort into themes and analyze: the act of manipulating visible indicators of language and literacy once again allowed thinking to be made explicit. 


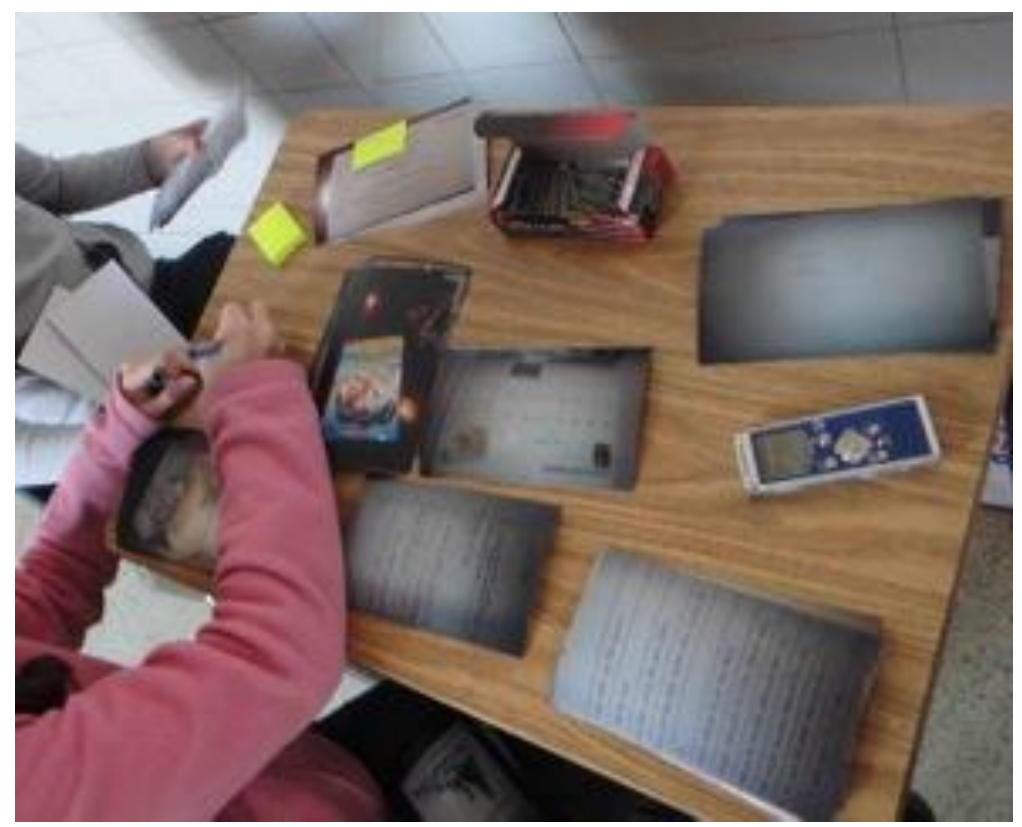

Figure 4: Students sorting literacy photos into piles according to theme

Plurilingual identity text creation.

Further to these four creative reflexive activities, I worked with classroom teachers, as well as language teachers (English, FSL, ESL) to engage students in creating plurilingual and multimodal identity texts. Cummins (2006) defines students' "identity texts" as,

[T] he products of students' creative work or performances carried out within [the pedagogical space of the classroom [...] insofar as students invest their identities in these texts (written, spoken, visual, musical, dramatic or combinations in multimodal form) that then hold a mirror up to students in which their identities are reflected back in a positive light. When students share identity text with multiple audiences [....] they are likely to receive positive feedback and affirmation of self in interaction with these audiences. (p. 60)

The parameters of students' plurilingual identity text creation are negotiated in collaboration with teachers and their students in relation to cross-curricular grade-level expectations at each school site. This identity text project is at the heart of the transformative multiliteracies classroom intervention in this inquiry as it provides an opportunity for students to integrate the cultural and linguistic resources that they identified through the creation of their self-portraits, their family language maps, as well as their home and school photography of language and literacy practices. In the remainder of this paper, I reflect particularly on how the process of plurilingual identity text creation was taken up in the case study at a French international school in Toronto, L'école Internationale and how it further scaffolded students' reflection on and representations of their plurilingualism. 
L'école Internationale

Participants.

École Internationale ${ }^{i i}$ is a private French international school in Toronto for students from pre-kindergarten to grade 12. The school attracts an upper middle class clientele who can afford private tuition ranging from $\$ 13000$ to $\$ 15000$ per year and generally desire an internationally recognized education in French. The school prepares students for the French Baccalauréat at the completion of grade 12 as established by the national Ministry of Education in France. The school was originally founded to meet the educational needs of children of French diplomats and ex-patriot executives; the French government covers the tuition for such students while they are abroad in Canada. The school hosts over 400 francophone, anglophone and CLD allophone students and it boasts that excellence in language instruction is at the heart of its mandate. Thus, while the medium of instruction for core subjects is French, students take English classes beginning from pre-Kindergarten through to grade 12 . The grade 5 students involved in this study received an hour of English instruction per day. In grade 6, students will begin taking Latin and also choose between Spanish and German as a required third language. Subsequently, they have the option to add Italian and/or Mandarin as a fourth language in grade 9. All 13 students in the grade 5 class participated in the project, along with their French teacher and their English teacher. Eight students' parent(s) also participated in interviews, along with two school administrators and the collaborating French and English teachers.

\section{Plurilingual Multiliteracies Intervention: Areating a Collaborative "Roman-photo"}

At the outset of the project, the participating French and English teachers decided to have students create plurilingual books to be published electronically and in hard copy. In the first term of the 2011-2012 school year, students were reading stories in English class about secrets and beginning a unit in French on Le secret du grand-père by Michael Morpurgo. To integrate the creative writing project with the regular classroom program, the teachers set out the criteria that students work in assigned pairs or threes to write a plurilingual story that involved a secret, could be divided into 8-12 illustrated double page spreads, and involve students themselves as characters within the story. The two teachers assigned groups according to students' third languages. For example, out of the 13 students in the class, 6 additional languages were used among their families: Spanish, Czech, Russian, Farsi, Serbian and Hebrew. Thus, six groups were formed including at least one student who had a third language in addition to English and French. This project was the first collaboration between the French and English teachers. Over the course of five weeks, students worked during two French expression ecrite periods and two English classes each week to draft, edit, type and illustrate their stories in French and English. The teachers recognized that by the end of the project all students would produce a plurilingual text so they did not explicitly prescribe students' language use throughout the process. Some groups wrote their stories entirely in French first, others wrote their story entirely in English, and others still wrote their stories stage by stage in English and French simultaneously. Once students' stories had been edited in English and French, 
students who had access to an additional language in their families took their story home to work on a translation in the third language. Students worked with parents, or other family members, to translate their story into the third language. Finally, students prepared audio recordings of themselves reading the stories in French, English and when possible in the third language. The stories were prepared as portable document files that were printed professionally and bound as hard copies, as well as e-books via a free web platform at www.issuu.com, and then hosted on the class blog.

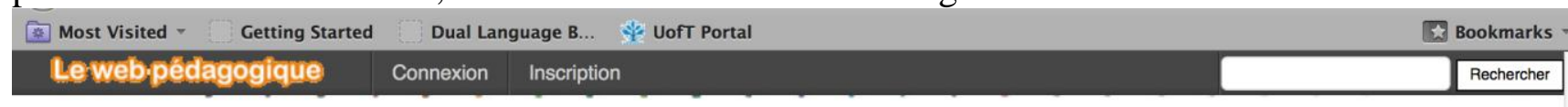

内rss

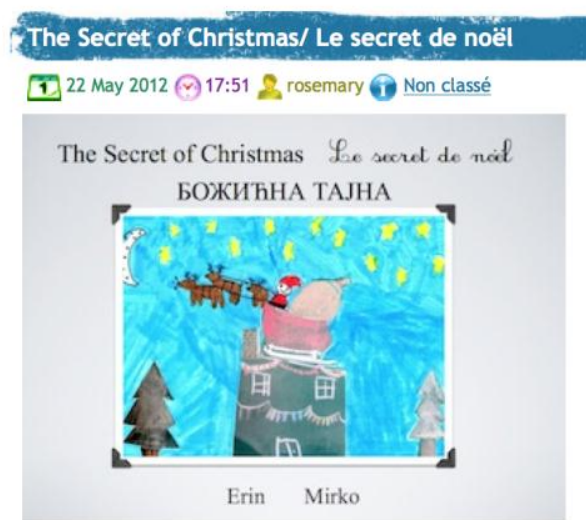

There is a big man in the woods hurt from the cold. The elves come to get him and bring him to a factory. When he wakes up he finds red and white clothes in the elves hands. What is going on?

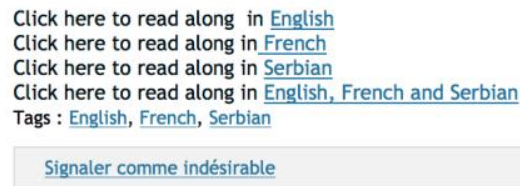

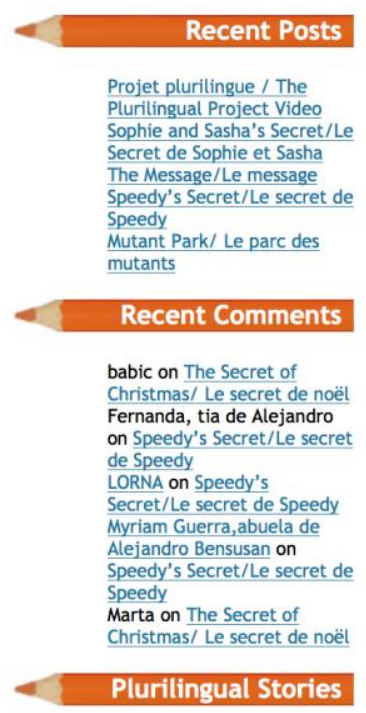

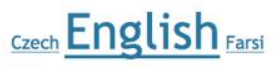

French ${ }_{\text {Hebrew Russian }}$

\section{2 commentaires comments}

Figure 5: Screenshot of class blog hosting students' plurilingual e-books

The teachers and researcher planned a book launch to which families were invited and students received print copies of their books. In addition, both the English and French teachers arranged for students to read their stories to other students in younger grades. These multiple opportunities for sharing allowed students to receive positive feedback about their plurilingual work and showcased the range of their linguistic and creative abilities.

In order to help students reflect on the process of the plurilingual project, students engaged in three different activities. First, they created a collage in response to the prompt "How does it look and feel to be plurilingual?"; then they wrote a personal statement akin to an artist statement about their individual involvement with the plurilingual project; and finally, students created four reflexive drawings of a 
monolingual person, a bilingual person, a plurilingual person and themselves. Students presented both their collages and drawings to the entire class as a way of generating reflective discussion about their different views of and experiences as plurilingual.

Issues \& Insights from L'école Internationale

The focus in the remainder of this paper is to reflect on the issues and insights that emerged through the plurilingual identity text creation process and to link it both to TMP (Cummins, 2009) and to engaging students to become multiliteracies co-researchers. The process of having students create plurilingual stories in groups integrated all five principles of Transformative Multiliteracies Pedagogy. From the outset, the project positioned students as intelligent, imaginative and linguistically talented. All students were able to work on the creation and translation of their stories in French and English; students with an additional language further shared their language with their group. The teachers and researchers had decided to group students in pairs or groups of three at the outset of the project in order to help facilitate that process. As this case was designated as a pilot, we were not entirely sure at the outset how long each stage of the process would take.

The grouping of students served to help increase all students' language awareness and curiosity about the linguistic and cultural diversity within the class. Furthermore, for students who contributed a third language to their group's stories, this sharing provided an opportunity to acknowledge and build on their diverse cultural and linguistic competencies. In a sense, while the students were in the process of writing stories about imaginary secrets, they were at the same time revealing secret or hidden linguistic abilities. It was surprising to learn that despite the fact that many of the students had been in the same classes as their peers since kindergarten, they were unaware of the other languages students used at home beyond French or English. In their reflections about their plurilingual writing, one bilingual French-English student wrote, "This work is important to me because I learned a couple of words in Farsi." Another student wrote, "I learned that it is not as easy as it seems [to make a book]. And I also learned a bit of Spanish because I was typing it on the computer." Because her partner was absent during one of the project periods, this student had typed the Spanish translation that her partner had prepared at home with his dad. Even though not all the students spoke the third language in their group, over the course of the project, they began to take ownership for its inclusion in their story. By sharing experiences with the entire class, all students had opportunity to expand their language awareness and to reflect together on the value and role of different languages in their daily lives. Parents also reported that their children's interest in learning languages - either their own or others - grew through the collaborative process of writing and presenting their plurilingual stories. One mother recounted that her children had never displayed interest in learning her mother's first language, "they think it's something I imposed [pause] like eat your fruit [pause] or eat your vegetables [pause] So they're not very interested in doing it" (interview transcript). Reflecting upon her collaboration with her daughter to write the home language translation, she described,

I was surprised myself actually that I was able to write. I thought it would take a long time but basically no. We just sat and she was excited to see that it goes from 
this side (right) to this side (left) and that I knew how to write it [Farsi]. They weren't curious about this 'other' language for a long time and then the writing was like [pause] it was a good thing and she was happy that I could actually do it for her [book]... she doesn't have Farsi herself but it kind of opened up the door a little bit. Like she now thinks she's more interested [...] I've got books from first grade Farsi so I may try a little bit. (interview transcript)

During the book launch celebration with invited family members and guests, one mother recounted to me that her daughter had come home from school and told her about all the different languages that other kids spoke in the class and that really motivated [her daughter] to want to start German classes next year (researcher notes, 05.05.12).

Some of the most significant learning emerged from the French and English teachers working together to address issues of language, writing and translation. Lyster, Collins and Ballinger (2009) have highlighted how challenging language teacher collaboration can be to implement because of a lack of time provided in teachers' schedules for meeting together. Although many students approached the process of translating their stories from French to English or vice versa as a linear process, they developed an understanding that one cannot translate from one language to another wordfor-word / mot-à-mot. Both the English and French teacher were able to highlight the use of authentic examples from student writing that students needed to translate meaning and sense rather than "just the words"; furthermore, they were able to show students where in their writing they were borrowing grammatical constructions from their first language be it English or French. For example, one group wrote first in French, "Ils font leur chemin..." By comparing this sentence to their English translation later, "They make their way to...", the French teacher was able to highlight for the students how they had written their French sentence while thinking in English rather than formulating it in French more authentically as "Ils marchent vers...".

By writing in more than one language, students came to appreciate that different languages (and cultures) have different modes of thought and expression. Students also became aware of different conventions of print. In Farsi, students recognized that the script should be read from right to left rather than left to right like in English and French. This realization prompted further discussion of the directionality of print. Some students who were taking Mandarin classes were able to share that some languages are also read vertically. Finally, the English and French teacher were able to capitalize on opportunities to teach for cross-linguistic transfer, to recognize les faux-amis in French and English, as well as to highlight shared cognates - or words that share the same root. For example, in one group's story the students wrote first in French, "Regarde Max, nous ne sommes pas des imbéciles!" When translating their text into English, they wrote "Look, Max, we're not imbeciles!" The two boys who wrote this story developed a complex text in French and in English in part because they were able to borrow les vrais amis in French and English to elevate their diction across both languages. As another example of teaching for transfer, we were able to use the book covers of students' printed proofs to review capitalization rules in English and French (see Figures 6-7). 


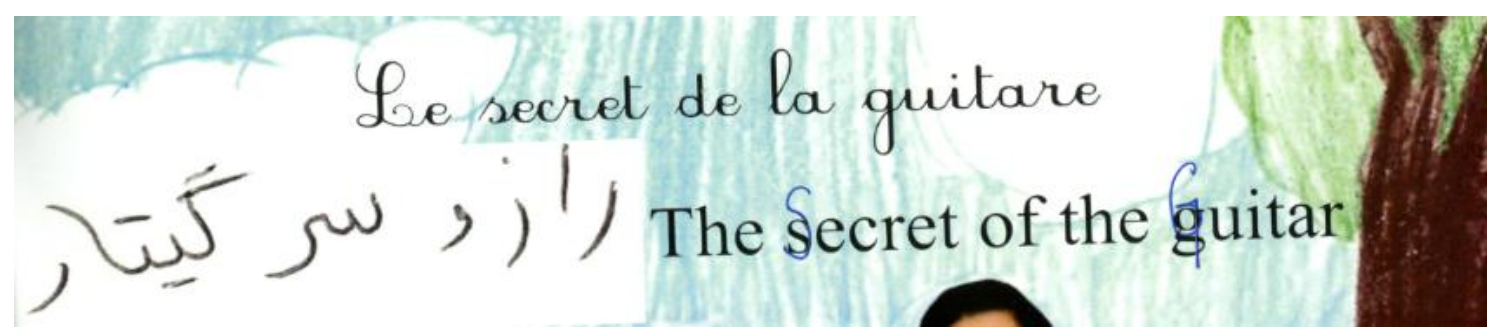

Figure 6: Extract of edited book cover

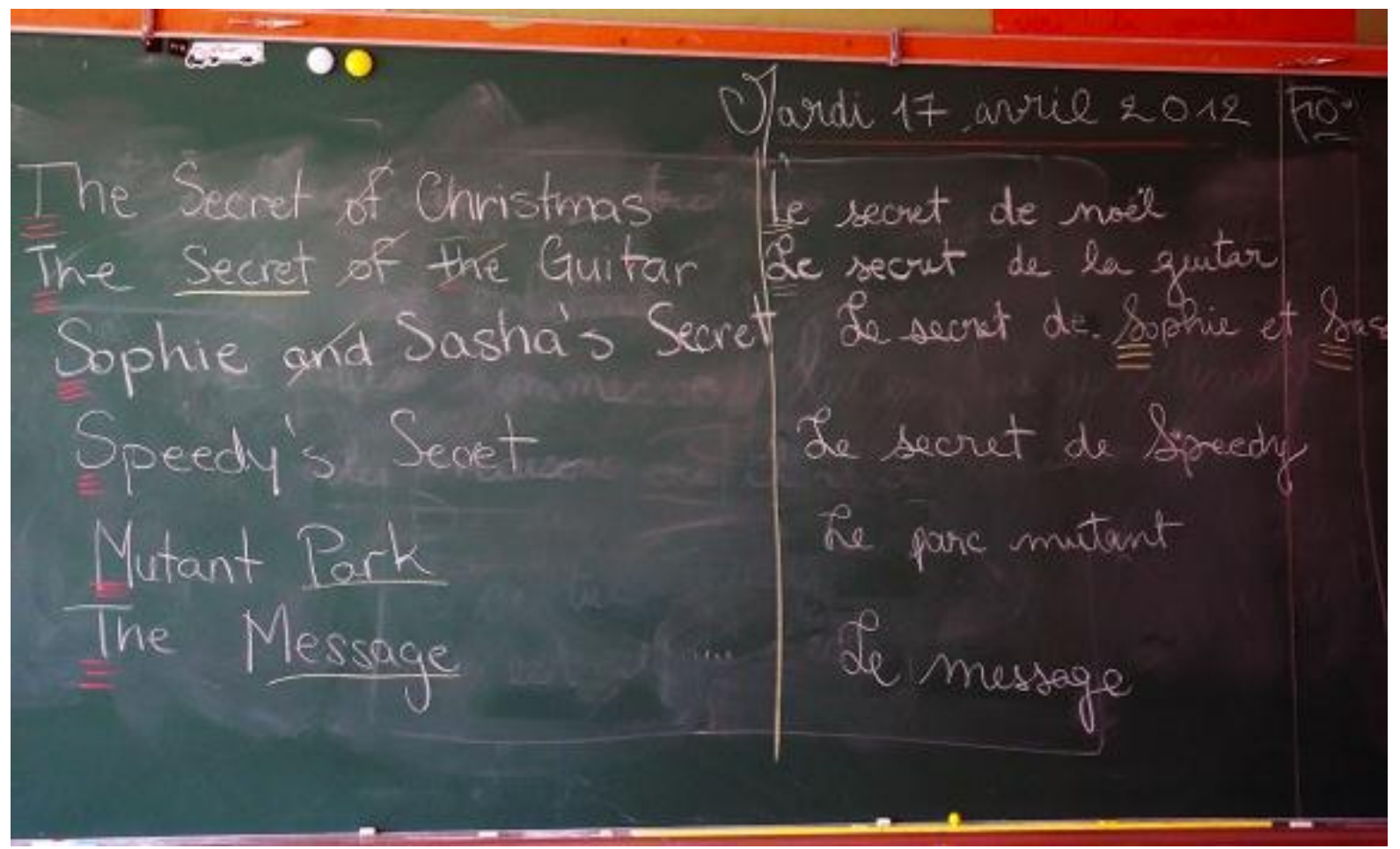

Figure 7: Comparing capitalization of titles in English and French

Whereas in French, titles are not capitalized apart from the first word, in English key words in titles are capitalized. We moved beyond title capitalization rules to further compare English and French capitalization rules of the days of the week and the months of a year. In a post-interview, the English teacher reflected that she had recognized the importance of making connections between the two languages in her instruction. The French teacher further underlined that this did not mean he had to teach in English, but that he could briefly make reference to English in order to draw on students' prior knowledge and linguistic competencies to scaffold their learning. As a tangible response to this project, the school administration planned to integrate collaborative planning time in the schedules for English and French elementary teachers.

Throughout the project, we (researcher and collaborating teachers) also noted the deep level of engagement on the part of the students. In his observation in class early in the project, the French teacher noted that he felt like he was doing very little, even while all of the students were actively at work. He reflected that it was not the traditional "classique" way of teaching with the teacher at the front of the classroom and the 
students at their desks, but as he looked around the classroom, students were all focused in their groups, discussing or writing their stories. Both the English and French teacher commented that it took more preparation to set up the plurilingual identity text project, but once the directions were given and expectations set, the teachers became facilitators of the process rather than focal figures. Students themselves became central. The power of choice was released to them to negotiate how they completed the task; that is, what language they used to communicate with one another, how they went about writing their stories in each of the languages, how they illustrated their pages with photographs and drawings, and who would be responsible for reading the various parts of the story for their audio recordings. The teachers became guides along the publishing journey and the responsibility of designing their plurilingual projects rested with the students themselves.

At the conclusion of the project, the French teacher reflected that by engaging students in publishing plurilingual identity texts,

LOJon a reussi a faire ce qu'on doit faire tout l'année. Normalement on doit faire ça tout l'année depuis la troisième année, et regard, c'est la cinquième. On doit écrire, et surtout corriger, recommencer, presenter un travail propre, mais c'est difficile parce que c'est long et les enfants s'ennuient vers la fin. [English gloss: We managed to do what we need to be doing all year. Normally, we should be doing this all year from grade 3 and here we are in grade 5. We need to write, edit and edit again, prepare a polished copy, but it's hard because it takes a long time and children become bored towards the end.]

This teacher's reflection highlights the role of student agency and engagement both in the learning and research process. Students responded positively to the opportunity to direct their own learning by making decisions about their writing and their freedom to draw on and invest all of their cultural and linguistic abilities in their work. Students' motivation was sustained throughout the project because it was both personally meaningful to them and they knew from the outset that it would be shared with a wide authentic audience beyond their teachers and even their parents. As one student put it, "This work is important to me because all my hard work equaled to something extraordinary that I did. It's not a test and I don't have to study, I'm [pause] exploring another side of myself'. Over the course of the case study, students engaged both in the creation of identity texts and in creative reflection about the significance and value of their plurilingual competence in their school life and their social lives.

How does this work help us understand how students conceptualize their plurilingualism? Students provided a range of responses in their reflective writing after completing their stories and in preparation to share them at the book launch, as well as through follow-up interviews. Students were overwhelmingly proud of the fact that their stories were published as "real" books. In terms of their reflection on their plurilingualism, one student wrote, "making a book in a different language is special to me because I can read all the languages and that makes me proud." Another student shared in an interview that when she sees her plurilingual book, it makes her feel "original" - no other student in the class can speak and read and write in the three languages that she does and that makes her special. Yet, another student wrote about his 
work with his partner, "when I was writing this book, I learned that two minds full of imagination can do something big and creative. I also learned about other languages." We see in the reflection of these students that by working on a plurilingual project, students have drawn on the range of their creative and linguistic competencies and come to see themselves as talented, plurilingual authors. One mother summarized the significance of the plurilingual project for her daughter in the following way:

I think sometimes you need to mirror back to a child what they have because they take what they have, not for granted, but it hasn't been named, or made apparent to them as a gift possibly...so having the school and you [a researcher] pay attention to that is a way of saying to them 'Hey, you guys have gifts, like this is a really lucky thing that you have access to another language because languages don't just open up oral expression, they open up access to culture, histories[...] and other people and that's actually really valuable.' [...] I think it's also powerful when it comes from teachers because sometimes as a parent when you hold a mirror up to a child to say, 'This is the wonderful gifted person I see you are [...]' It's like, 'O whatever mom.' [...] I think they are pleased on one level, but you as a parent sometimes don't have as much weight. But when an external person validates that, it gives them a level of thoughtfulness about themselves that they don't necessarily get when it's just a parent mirroring back. You're good at this and this is valuable - when it's valued elsewhere, it's really solid reinforcement. (interview transcript)

By engaging students in a plurilingual identity text project, along with a series of artsinformed research activities, students are able to develop and represent their views about plurilingualism and reflect on the value and use of pluri-literacies in their daily lives. Students' photographs of literacy practices at home and school, as well as their collages about how it looks and feels to be plurilingual provide evocative visual insight into their understanding of plurilingualism and their pluri-literacies. Three students' final collages are showcased in the following series of images. 


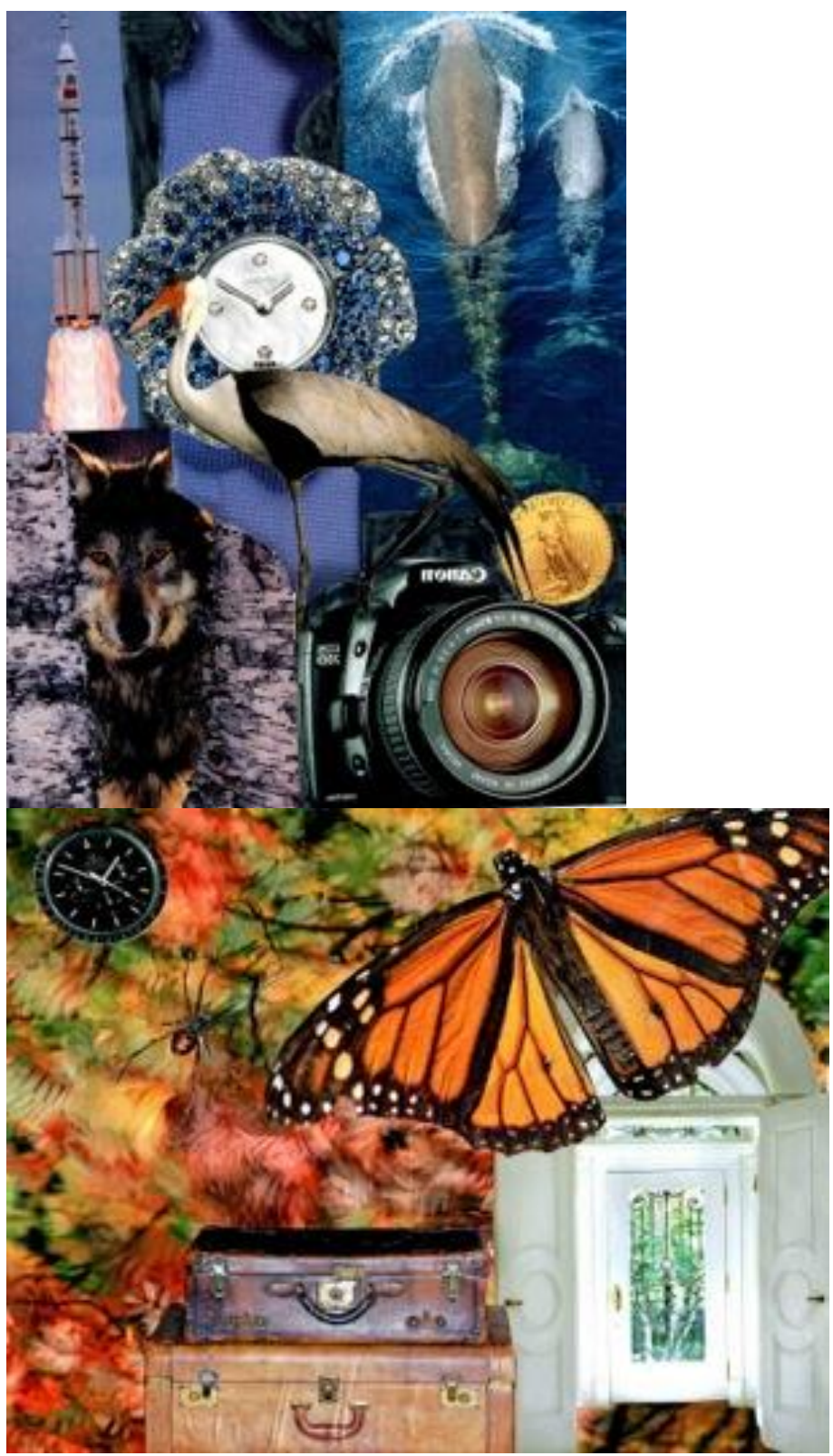

Language and Literacy $\quad$ Volume 15, Issue 3, Special Issue 2013

Page 24 


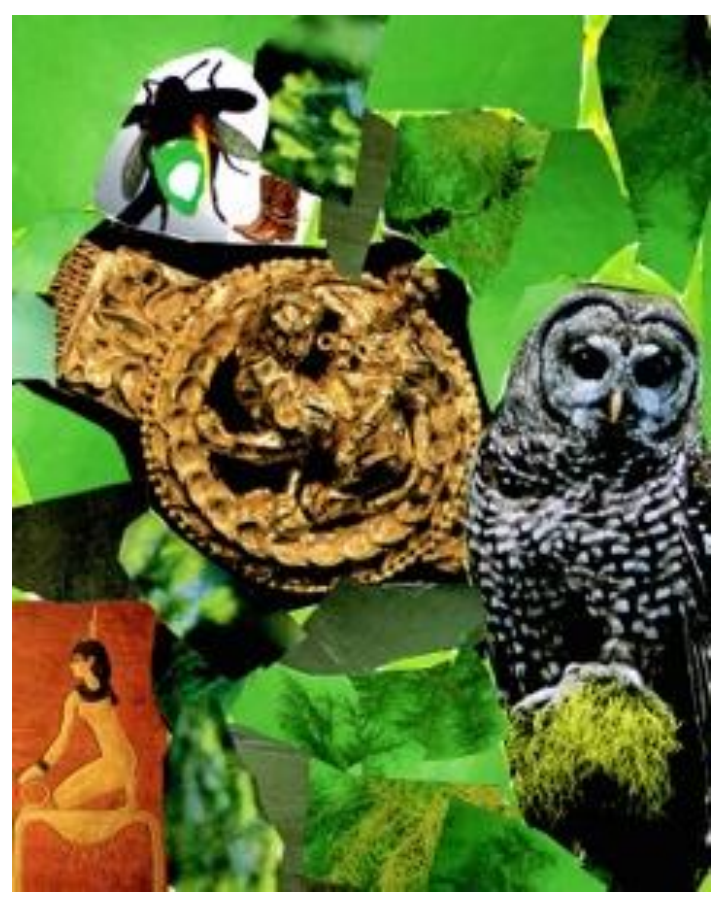

Figures 8-10: Three students' final reflective collages

Students' collages resist a traditional linear written description. The evocative juxtaposition and layering of images invites multiple viewings and readings. Indeed, during a closing gallery-walk designed based on the "Markus Approach" (Butler-Kisber, 2010, p.105), students were able to both respond to one another's collages and explain their own interpretations. The sharing process unfolded intuitively as a student-directed focus group where children individually and collectively made sense of their plurilingualism.

Conclusion: Imagining Possibilities for Alter(n)ative Language and Literacy Inquiry

The question remains, how can we re-envision the reporting of plurilingual multiliteracies research in ways that authentically represent both the creative inquiry process and its product(s), as well as facilitate the return of the research to the students, their families and the collaborating educators? What multimodal and plurilingual forms are best suited for and might we draw upon to disseminate our research with children in ways that respond to the criteria of the academy and remain accessible to children as coresearchers and their communities? This initial case study positioned plurilingual children as legitimate co-researchers of their own language and literacy practices. I supported students to become co-researchers by purposefully drawing upon creative visual techniques and tools to facilitate their data collection and generation. I have conceptualized this type of collaborative art-informed inquiry as alter(n)ative inquiry: alternative in the sense of drawing on non- traditional but legitimate approaches to research; and, alter-ative in the sense that participant-research collaborators are "changed" or transformed through the inquiry in that they take on new roles and identities of power (Prasad, 2009; 2012a; 2012b). Through their participation in the research activities in this case study, students came to see themselves and each other as unique 
plurilinguals with valuable insights to contribute to real-world issues pertaining to linguistic diversity, equity and inclusion in school and society. As an initial exploratory study, the questions provoke further consideration of how we may each expand our research repertoires to be attentive to voices and practices that have been traditionally excluded in mainstream approaches to language and literacy research.

\section{References}

Albanese, P. (2009). Children in Canada today. Toronto, ON: Oxford University Press.

Auger, N. (2010). Élèves nouvellement arrivés en France: Réalités et perspectives pratiques en classe. Paris, FR: Éditions des archives contemporaines.

Belanger, N., \& Connelly, C. (2007). Methodological considerations in child-centered research about social difference and children experiencing difficulties at school. Ethnography and Education, 21(1), 21-38.

Bucknall, S. (2012). Children as researchers in primary schools: Choice, voice and participation. New York, NY: Routledge.

Busch, B. (2010). School language profiles: Valorizing linguistic resources in heteroglossic situations in South Africa. Language and Education, 24(4), 283294.

Busch, B., Jardine, A., \& Tjoutuku, A. (2006). Language biographies for multilingual learning (Vol. 24). Cape Town, ZA: PRAESA Occasional Papers.

Butler-Kisber, L. (2010). Qualitative inquiry: Thematic, narrative and arts-informed perspectives. Los Angeles, CA: SAGE Publications.

Cappello, M. (2005). Photo interviews: Eliciting data through conversations with children. Field Methods, 17(2), 170-182.

Castellotti, V., \& Moore, D. (2009). Dessins d'enfants et constructions plurilingues. Territoires imagés et parcours imaginés. In M. Molinié (Ed.), Le dessin réflexif. Élément pour une herméneutique du sujet plurilingue (pp. 45-85). Paris, FR: Centre de Recherche Text Francophonies (CRTF)- Encrages, Belles Lettres.

Ceginskas, V. (2010). Being 'the strange one' or 'like everybody else: School education and the negotiation of multilingual identity. International Journal of Multilingualism, 7(3), 211-224.

Christensen, P. M., \& James, A. (2008). Research with children: Perspectives and practices (2nd ed.). Abingdon, UK: Routledge.

Clark, A. (2004). The mosaic approach and research with young children. In V. Lewis, M. Kellet, C. Robinson, S. Fraser \& S. Ding (Eds.), The reality of research with children and young people. (pp. 157-180). Thousand Oaks, CA: SAGE Publications.

Corsaro, W. A. (1981). Entering the child's world - Research strategies for field entry and data collection in a preschool setting. In J. Green \& C. Wallat (Eds.), Ethnography and language in educational settings. (pp. 117-146). Norwood: Ablex.

Coste, D. (2001). De plu d'une langue à d'autres encore. Penser les compétences plurilingues. In V. Castellotti (Ed.), D'une langue à d'autres. Pratiques et représentations. (pp. 191-202). Rouen, FR: Pressess universitaires de Rouen. 
Coste, D. (Ed.). (2005). Plurilinguisme et apprentissages. Lyon, FR: École normale supérieure.

Coste, D. \& Simon, D-L. (2009). The plurilingual social actor. Language citizenship and education. International Journal of Multilingualism. 6 (2), 168-185.

Council of Europe. (2001). Common European framework of references for languages: Learning, teaching, assessment. (CEFR). Cambridge, UK: C.U.P.

Cummins, J. (2001). Negotiating identities: education for empowerment in a diverse society (2nd ed.). Ontario, CA: California Association for Bilingual Education.

Cummins, J. (2006). Identity texts: The imaginative construction of self through multiliteracies pedagogy. In O. Garcia, T. Skutnabb-Kangas \& M. E. TorresGuzman (Eds.), Imagining multilingual schools: Language in education and glocalization (pp. 51-68). Toronto, ON: Multilingual Matters Ltd.

Cummins, J. (2009). Transformative multiliteracies pedagogy: School-based strategies for closing the acheivement gap. Multiple Voices for Ethnically Diverse Exceptional Learners, 11, 38-56.

Cummins, J. (in press). Rethinking monolingual instructional strategies in multilingual classrooms. Canadian Journal of Applied Lingusitics.

Dagenais, D., \& Berron, C. (2001). Promoting multilingualism through French Immersion and language maintenance in three immigrant families. Language, Culture and Curriculum, 14(2), 142-155.

Dagenais, D. \& Jacquet, M. (2008). Theories of representation in French and English scholarship on multilingualism. International Journal of Multilingualism, 5(1), 41-52.

Dagenais, D., \& Moore, D. (2004). Représentations ordinaires du plurilinguisme, transmission des langues et apprentissages chez des enfants, en France et au Canada. Langages 154, 34-46.

Dagenais, D., \& Moore, D. (2008). Représentations des littératies plurilingues, de l'immersion en français et des dynamiques identitaires chez des parents chinois. Canadian Modern Language Review, 65(1), 11-31.

Dagenais, D., Moore, D., Sabatier, C., Lamarre, P., \& Armand, F. (2009). Linguistic landscape and language awareness. In E. Shohamy \& D. Gorter (Eds.), Linguistic landscape: Expanding the scenery. New York: Routledge.

Farmer, D. (2012). Portraits de jeunes migrants dans une école internationale au Canada. La revue international de l'éducation familiale. 31, 73-94.

Farmer, D., \& Labrie, N. (2008). Immigration et francophonie dans les écoles ontariennes: comment se structurent les raports entre les institutions, les parents et le monde communautaire? Revues des sciences se l'éducation, 34(2).

Freeman, M., \& Mathison, S. (2009). Researching children's experiences. New York, NY: Guilford Press.

Garcia, O., Barlett, L., \& Kleifgen, J. (2007). From biliteracy to pluriliteracies. In P. Auer \& L. Wei (Eds.), Handbook of multilingualism and multilingual communications. New York, NY: Mouton de Gruyter.

Garcia, O., Skutnabb-Kangas, T., \& Torres-Guzmán, M. E. (Eds.). (2006). Imagining multilingual schools: Language in education and glocalization. Toronto, ON: Multilingual Matters Ltd. 
Gauntlett, D. \& Holzwarth, P. (2006). Creative and visual methods for exploring identities. Visual Studies, 21(1), April 2006, 82-91

Gérin-Lajoie, D. (2003). Parcours iidentitaires de jeunes francophones en milieu minoritaire. Sudbury, ON: Prise de Praole.

Gérin-Lajoie, D. (2006). La contribution de l'école au processus de construction identitaire des élèves dans une société pluraliste. Éducation et francophonie, $34(1), 1-7$.

Gérin-Lajoie, D. (2008). Le rôle contradictoire de l'école dans la construction des identités plurilingues. , Éducation et sociétés plurilingues, 24, 27-39.

Goldstein, T. (2003). Teaching and learning in a multilingual school: Choices, risks and dilemmas. New York, NY: Lawrence Erlbaum Associates.

Heydon, R., \& Iannacci, L. (2008). Early childhood curricula and the de-pathologizing of childhood. Toronto, ON: University of Toronto Press.

Jedwab, J. (2004). Language matters: Analysing the next act on federal official language policies. Policy Options, 81-86.

Kendrick, M., \& Jones, S. (2008). Girls' visual representations of literacy in a rural Ugandan community. Canadian Journal of Education, 31(2), 371-404.

Kendrick, M., \& Mckay, R. (2004). Drawings as an alternative way of understanding young children's constructions of literacy. Journal of Early Childhood Literacy, 4, 109-128.

Knupfer, A. M. (1996). Ethnographic studies of children: the difficulty of entry, rapport, and presentations of their worlds. Qualitative Studies in Education. 9 (2), 135149.

Krumm, H. (2008). Plurilinguisme et subjectivité: <<portraits de langues〉>, par les enfants plurilingues (A. Hu \& D. Vandystadt, Trans.). In G. Zarate, D. Lévy \& C. Kramsch (Eds.), Précis du plurilinguisme et du pluriculturalisme. Paris, FR: Éditions des archives contemporaines.

Lahire, B. (2011). The plural actor (D. Fernbach, Trans.). Malden, MA: Polity Press.

Lyster, R., Collins, L., \& Ballinger, S. (2009). Linking languages through a bilingual read-aloud project. Language Awareness, 18, 366-383.

Mady, C. (2006). The suitability of core French for recently arrived English-as-a-secondlanguage adolescent immigrants. (Unpublished doctoral dissertation). Ontario Institute of Studies in Education, Toronto, ON

Mady, C. (2007). Allophone students in French second-official-language programs: A literature review. Canadian Modern Language Review, 63(5), 727-760.

Majhanovich, S. (2010). Canadian language policies: An example of political expediency? In A. G. Macleans \& S. Majhanovich (Eds.), Education, language and economics: Growing national and global dilemnas. Rotterdam, NL: Sense Publishers.

Manyak, P. C. (2004). "What did she say?": Translation in a primary-grade English immersion class. Multicultural Perspectives, 6(1), 12-18. doi:

10.1207/S15327892mcp0601_3

Martin, B. (2012). Coloured language: Identity perception of children in bilingual programmes. Language Awareness, 21 (1-2), 33-56. 
Masny, D. (2009). Lire le monde: Les littératies multiples et l'éducation dans les communautés francophones. Ottawa, ON: Les Presses de l'Université d'Ottawa.

Molinié, M. (Ed.). (2009). Le dessin réflexif: Élément pour une herméneutique du sujet plurilingue. Cergy-Pontoise Cedex: Centre de Recherche Textes et Francophonies.

Moore, D. (2006). Plurilinguismes et école. Paris, FR: Didier.

Moore, D. \& Gajo, L. (2009). French voices on plurilingualism and pluriculturalism: theory, significance and perspectives. International Journal of Multilingualism. 6 (2), 137-153.

New London Group (1996). A pedagogy of multiliteracies: Designing social futures. Harvard Educational Review, 66, 60-92.

Ontario Ministry of Education. (2009). Realizing the promise of diversity: Ontario's equity and inclusive education strategy. Retrieved from http://www.edu.gov.on.ca/eng/policyfunding/equity.html.

Pahl, K. \& Roswell, J. (2007). Sedimented identities in texts: Instances of practice. Reading Research Quarterly. 42 (3), 388-404.

Peterson, S. S., \& Heywood, D. (2007). Contributions of families' linguistic and cultural capital to ESL students' literacy: Parents', teachers' and principals' perspectives. Canadian Modern Language Review, 63(4), 517-538.

Prasad, G. (accepted). "Portraits of plurilingualism in a French International School in Toronto:Exploring the role of the visual methods to access students' representations of their linguistically diverse identities." Canadian Journal of Applied Linguistics.

Prasad, G. (2012a). "Multiple minorities or plurilingual learners? Allophone immigrant children's rights and inclusion in French-language schools in Ontario" Canadian Modern Language Review. 68(2), 190-215.

Prasad, G. (2012b). Finding poetry: An alter(n)ative approach to language education research. In A. Cole, S. Stewart, \& S. Thomas (Eds.), The art of poetic inquiry. Halifax, NS: Backalong books.

Prasad, G. (2009). Alter(n)ative literacies: Elementary teachers' practices with culturally and linguistically diverse learners in one French-language school in Ontario. (master thesis). Retrieved from http://hdl.handle.net/1807/18108

Prout, A. (2005). The future of childhood: towards the interdisciplinary study of children. London, UK : RoutledgeFalmer.

Ramanathan, V., and Morgan, B. (2007). TESOL and policy enactments: Perspectives from practice. TESOL Quarterly. 41(3), 447-463.

Ricento, T. and Cervatiuc, A. (2010). Language minority rights and educational policy in Canada. In J. Petrovic (Ed.), International perspectives on bilingual education: Policy, practice, and controversy, (pp. 21-42). Charlotte, NC: Information Age Publishing.

Smythe, S., \& Toohey, K. (2009). Investigating sociohistorical contexts and practices through a community scan: A Canadian Punjabi-Sikh example. Language and Education, 23(1), 37-57. 
Swain, M., \& Lapkin, S. (2005). The evolving sociopolitical context of immersion education in Canada: Some implications for program development. International Journal of Applied Linguistics, 15, 169-186.

Taylor, S. (2009). The caste system approach to multilingualism in Canada: Linguistic and cultural minority children in French immersion. In T. Skutnabb-Kangas, R. Phillipson, A. Mohanty \& M. Panda (Eds.), Social justice through multilingual education. (pp. 177-198) Toronto, ON: Multilingual Matters.

Thomson P (Ed.). (2008). Doing visual research with children and young people. New York, NY:Routledge.

Wong-Fillmore, L. (2000). Loss of language: Should educators be concerned? Theory into Practice, 39, 203-210.

Wong-Fillmore, L. (2005). When learning a second language means losing the first. In M. Suàrez-Orozco, C. Suàrez-Orozco, D. Baolian Qin \& D. Qin-Hilliard (Eds.), The new immigration: an interdisciplinary reader. New York, NY: Routledge.

Zarate, G., Lévy, D., \& Kramsch, C. (Eds.). (2008). Précis du plurilinguisme et du pluriculturalisme. Paris, FR: Éditions des archives contemporaines.

\section{Author Biography}

Gail Prasad is a PhD Candidate in the department of Second Language Education at the Ontario Institute for Studies in Education. Her research focuses on children's plurilingualism and literacy practices in English and French schools in Canada and France. Her work is supported by a Joseph Armand-Bombardier Canada Graduate Scholarship.

\footnotetext{
${ }^{\mathrm{i}}$ Participants in this study were given the choice to use their first name or a pseudonym in the research sharing of their representational artifacts. Given that students produced "identity text", it is only fitting that students receive credit for their work, if they so desired. Where students and their parents preferred to remain anonymous, pseudonyms have been used.

ii The name of the school has been changed to protect the privacy of participants.
} 